\title{
MOTIVATION AS A PATH IN IMPROVING ACCOUNTING UNDERSTANDING
}

\author{
Keumala Hayati ${ }^{*}$ \\ University of Prima Indonesia \\ 1, Sekip St., Medan, \\ Indonesia 20111 \\ keumalahayatihakim@gmail.com
}

\author{
Bayu Wulandari ${ }^{2}$ \\ University of Prima Indonesia \\ 1, Sekip St., Medan, \\ Indonesia 20111 \\ bayuwulandari@unprimdn.ac.id
}

\author{
Munawarah ${ }^{3}$ \\ University of Prima Indonesia \\ 1, Sekip St., Medan, \\ Indonesia 20111 \\ noramunawarah88@gmail.com
}

\begin{abstract}
This study analyzes emotional intelligence, lecturer teaching style, and accounting understanding through motivation and learning behavior. The sample in this study was 239 respondents. Data is processed using SEM path analysis. This study indicates that motivation plays a vital role in teaching and learning success, as measured by understanding accounting. Good emotional intelligence can produce the right motivation. Competent and productive lecturers will be able to foster student motivation to produce high levels of understanding.
\end{abstract}

Keywords: Emotional intelligence; Motivation; Learning behavior; Lecturer teaching style; Accounting understanding

ABSTRAK
Penelitian ini bertujuan untuk menganalis pengaruh kecerdasan emosional, gaya mengajar dosen, dan fasilitas terhadap pemahaman akuntansi melalui motivasi dan perilaku belajar. Sampel dalam penelitian ini sejumlah 239 responden. Data diolah dengan menggunakan analisis jalur SEM. Hasil dari penelitian ini menunjukkan bahwa motivasi memainkan peranan penting dalam keberhasilan proses belajar mengajar yang diukur dengan pemahaman akuntansi. Kecerdasan emosional yang baik dapat menghasilkan motivasi yang baik. Dosen yang berkompeten dan produktif akan dapat menumbuhkan motivasi belajar mahasiswa yang akan menghasilkan tingkat pemahaman yang tinggi.

Kata Kunci : $\quad$ Kecerdasan emosional; Motivasi; Perilaku belajar; Gaya mengajar dosen; Pemahaman akuntansi

JEL Classification: A220; M490

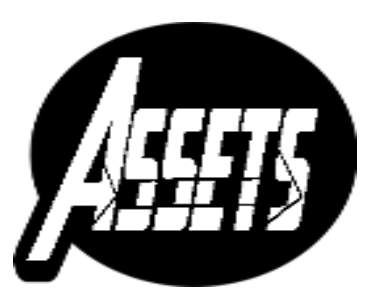

ASSETS

Jurnal Akuntansi dan Pendidikan

Vol. 9 No. 2

Page 131-141

Madiun, October 2020 p-ISSN: 2302-6251

e-ISSN: 2477-4995

Article History Submitted:

September 2, 2019 Accepted:

October 6, 2020 


\section{INTRODUCTION}

Education has become a measuring tool in human development to enable life to be useful and meaningful and contribute to society's development (Ramaraju, 2015). Education is an effort made by humans to improve the standard of life to a more perfect (Hariyoga \& Suprianto, 2011). A good education, it is necessary to understand the learning material presented to be applied in life properly. It takes concentration and feedback from students and lecturers. However, there are still many problems with the lack of concentration in student learning in class (Susanti, Rispantyo, \& Kristianto, 2017).

Many things must be considered to create quality students who can understand the lessons given by the lecturer, especially in terms of the teaching system delivered by the teacher in the room in the weight of the lessons delivered, for example, the emotional intelligence of students (Hariyoga \& Suprianto, 2011; Iin Sunarti, 2018; Parauba, 2014; Riswandi \& Lakoni, 2017; Rokhana \& Sutrisno, 2016; Susanti et al., 2017), lecturer teaching style, (Budiadi \& Sulistyawati, 2013; Munawarah, 2019) and others. In lecturing activities, full concentration should be needed to get satisfying results to understand and comprehend the subjects taught. However, the fact is that there are still many problems with the lack of concentration in student learning in class (Susanti et al., 2017). How do you reach a sound understanding? A good understanding, of course, there is a need for cooperation between lecturers and students. This research focuses on what factors can make understanding of lessons better.

Introductory accounting courses are courses that discuss the basic sciences of accounting that must be taught to students of the economics faculty in the first year, both in public and private universities. This course is also a determinant for students to take advanced courses. If a student does not pass an introductory accounting course, they cannot take the next course. To gain an in-depth knowledge of accounting theory, knowledge of accounting basics is a primary key. With a basis as a guideline for all accounting practices and theories, it will be easy to implement. Accounting courses are also subjects that require a high level of concentration to gain understanding. Not only that, lecturers who teach accounting courses must also be able to manage classes well. This study focuses on achieving an understanding of accounting under study in terms of students and faculty abilities. The lecturer's teaching style here functions as a shape for student learning behavior, whether it is getting better or vice versa.

The purpose of this study is to analyze the factors that influence the level of understanding of accounting. This study uses path analysis, namely motivation and learning behavior. Hariyoga \& Suprianto, (2011) stated that many determining factors in the teaching and learning process succeed in achieving adequate understanding. A good understanding can be achieved if there is a motivation that moves it. Motivation plays a strategic role because no one will want to learn without motivation (Nuraini, 2017).

Motivation is a conscious effort to move, direct, and maintain a person's behavior so that he is compelled to act to do something to achieve specific results or goals (Hamdu \& Agustina, 2011). Motivation is considered an essential factor for success as a mental impulse that moves and directs human behavior. In motivation, there is a desire to activate, move, channel, and direct attitudes and behaviors in individual learning (Dimyati \& Mudjiono, 2006; Steenkamp, Baard, \& Frick, 2009). Motivation influences the understanding of introductory accounting (Hamdu \& Agustina, 2011).

Learning behavior is a learning habit carried out by individuals repeatedly to become automatic or occurs spontaneously. Learning behavior does not feel like a 
burden, but rather a need (Hariyoga \& Suprianto, 2011). The behavior is created because it is continuously carried out with guidance and supervision and role models in all aspects and education creativity. The better the behavior of learning in someone, the easier it will be to understand the introductory accounting (Sari, 2013). Students who have no background in accounting, when they change their way of learning and start to like accounting in the first year, these students will be more successful in understanding accounting in the future (Öztürk \& Kutlu, 2017).

Accounting for higher education's success is also inseparable from emotional intelligence, namely mental attitude and the ability to read oneself about aspects of a student's personal psychology in developing his personality. The more activities or experiences of someone in the organization and the higher work experience (Inayah, Martono, \& Sawiji, 2013). Accounting education must strive to instill emotional intelligence in each graduate in addition to practice.

Emotional intelligence influences learning behavior because emotional intelligence determines $80 \%$ of personal and social success in life (Hariyoga \& Suprianto, 2011). Another factor is the lecturer's teaching style, which directly influences student learning (Frunză, 2014; Hackathorn, Solomon, Blankmeyer, Tennial, \& Garczynski, 2011). Competent lecturers can be seen from how far the lecturer mastered the material and can apply appropriate learning models for the studied (Budiadi \& Sulistyawati, 2013).

A good interpersonal relationship between lecturer and student will build a supportive, reflective, and communicative learning environment and, in the end, can create a quality learning process. Accounting students 'perceptions of the quality of lecturers can influence students' interest and motivation in accounting.

A productive lecturer contributes more to success and can grow student motivation than lecturers who are not productive and do not involve students (Hein et al., 2012). Lecturer's teaching style influences learning behavior. The lecturer's teaching style influences motivation (Hein et al., 2012; Munawarah, 2019). The lecturer's teaching style influences accounting understanding (Iin Sunarti, 2018; Iskandarsyah \& Ghozali, 2012; Zhang, 2004).

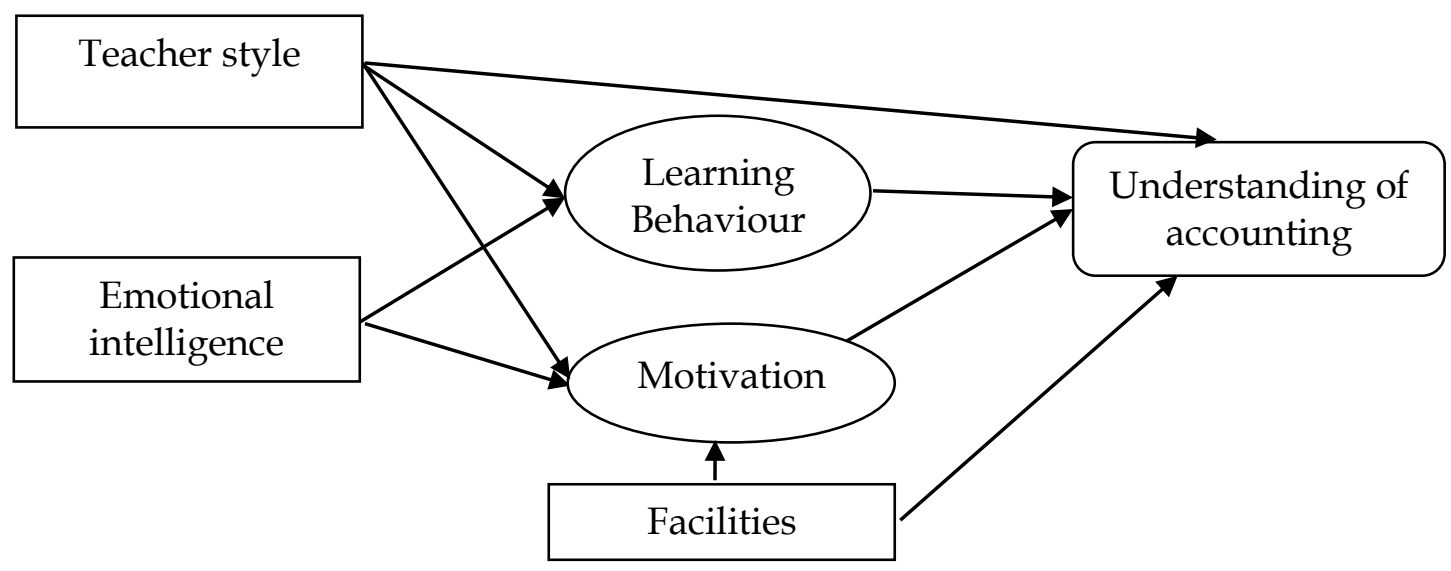

Figure 1. Research Model

Learning facilities are also among the most critical factors in achieving understanding in learning such as desks, chairs, blackboards, books, curriculum, stationery, teaching aids, and OHP (Inayah et al., 2013). The facility encourages student 
learning motivation to affect accounting's easy understanding (Budiadi \& Sulistyawati, 2013; Hamdu \& Agustina, 2011; Muhammad, Sapri, \& Sipan, 2014). This research is considered necessary because, with this research, it can be an evaluation material for lecturers as the main actors in the learning process for better understanding, especially in accounting.

\section{METHOD}

The data collection method in this study used a survey method by distributing questionnaires to a sample of students majoring in Accounting from the University of Prima Indonesia in the 2017/2018, who had attended the Introduction to Accounting course. The introductory accounting course was chosen because this course is the basis and determinant for taking further courses. The population in this study was 598 . Samples were selected using the Slovin formula, with 240 respondents. The number of questionnaires returned and 240 pieces, but can be processed as many as 239 pieces, while one more could not be processed due to incomplete filling. The data is processed by path analysis using AMOS 26 software. Before conducting the model's structural test, the model suitability test is carried out first to see which model is fit or not.

\section{RESULT AND DISCUSSION}

The following table describes the respondents' identities consisting of male and female students ranging in age from 18 to 22 years. The total respondents in this study were 239 .

\section{Table 1. Identity of Respondents}

\begin{tabular}{lc}
\hline \multicolumn{1}{c}{ Classification } & Total \\
\hline Age & \\
18 & 11 \\
19 & 66 \\
20 & 122 \\
21 & 29 \\
22 & 11 \\
Gender & \\
Male & 56 \\
Female & 183 \\
\hline Total & $\mathbf{2 3 9}$ \\
\hline
\end{tabular}

Table 2. Test Criteria for Goodness of Fit

\begin{tabular}{lccc}
\hline \multicolumn{1}{c}{ The goodness of fit index } & Cut of value & Score & Information \\
\hline Chi-Square & Expected to be small & 146,186 & Well \\
Profitability & $>0.05$ & 0.343 & Very good \\
GFI & $>0.90$ & 0.941 & Well \\
AGFI & $>0.90$ & 0.920 & Well \\
TLI & $>0.90$ & 0.992 & Well \\
RMSEA & $<0.08$ & 0.014 & Well \\
\hline
\end{tabular}

The model conformity test is performed first before structural testing. Table 2 displayed the Goodness of Fit test data. Table 2 shows that the whole model was fit with the sample data. It can be seen from the value generated. Chi-Square Value = 
146,186 with Profitability (P) 0.343 . Then it can also be seen from the results of GFI, AGFI, and TLI. All values are above 0.90. Likewise with RMSEA, which is worth 0.014, smaller than 0.08 . So it can be concluded that the model is fit and can be tested further.

\section{The Influence of Emotional Intelligence on Learning Behavior and Motivation}

Based on table 3, it can be seen that emotional Intelligence influences learning behavior. It can be seen from the value of P 0.004. Then emotional intelligence also affects motivation. It can also be seen from the P-value of 0,000. Student emotional intelligence refers to recognizing themselves, others, and the ability to motivate themselves and their relationships with others (Novianti, Farida, \& Widiartanto, 2015). Emotional intelligence can help students realize what must be achieved and their responsibilities in learning.

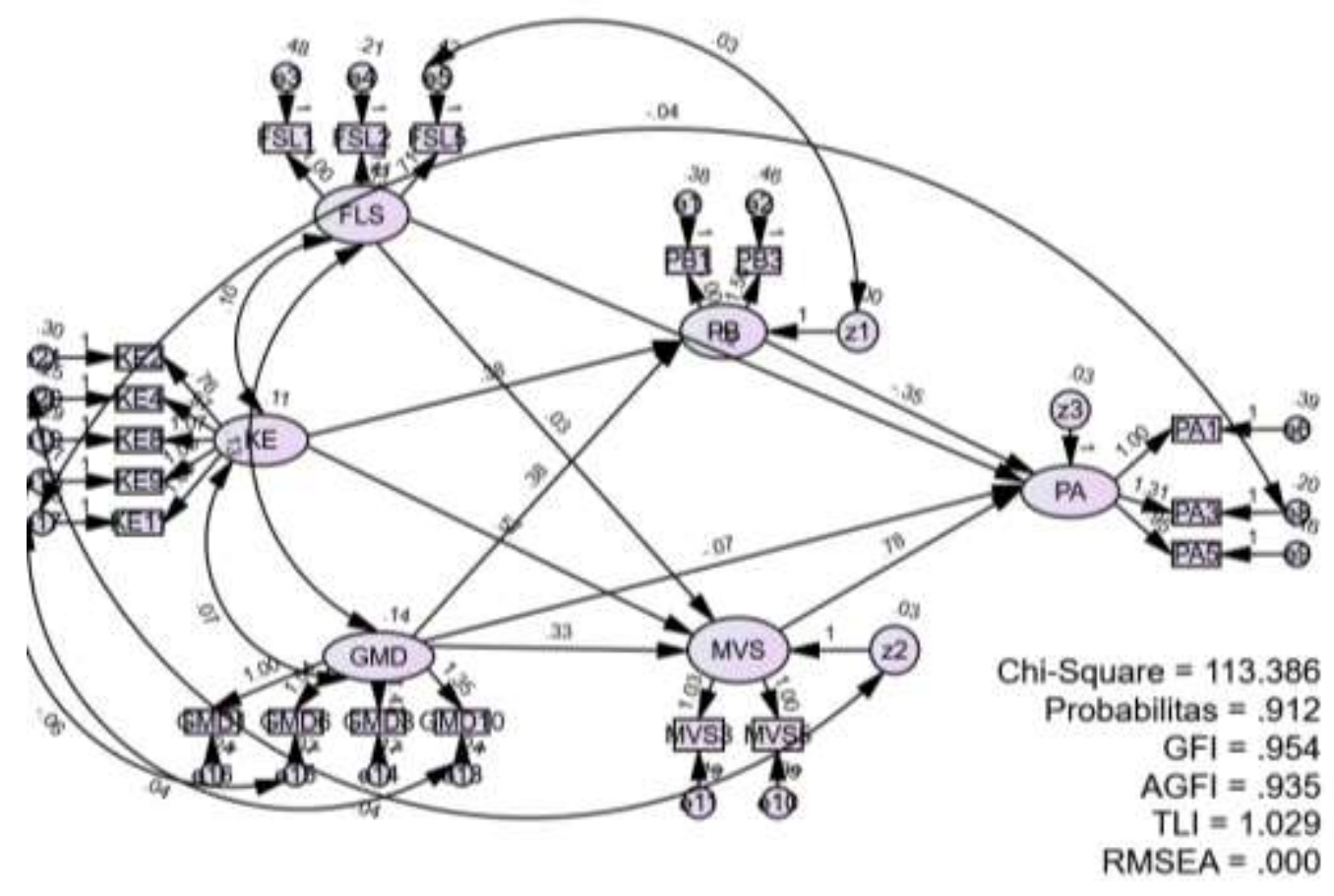

Figure 2. Research Results

Self-awareness of the importance of learning can change student learning behavior. Learning behavior is reflected by one's intention to reflect this learning behavior (Sideridis \& Kaissidis-Rodafinos, 2001). They were starting from the awareness not to delay work or assignments given by the lecturer. Students must be able to understand the lessons being delivered to complete the assignment. If a student feels unable to do the assignment, they will start looking for books or references from the library. Repeated visits to the library can make a habit that will not be felt like a burden anymore. Assignments given by lecturers will always be considered as exercises and not a big problem.

Awareness of the importance of learning that starts from themself by little will spread to the student's closest friend. So that student friends also began to feel that the task is not a burden. Emotional intelligence here plays a vital role in changing learning behavior. Emotional intelligence, which is the ability to control themselves and impact others, can increase motivation. Emotional intelligence can help students realize what must be achieved and their responsibilities in learning. Self-awareness of the (i) (2)

This work is licensed under a Creative Commons Attribution-ShareAlike 4.0 International License. 
importance of learning can foster student motivation, that all must start from themself. This research is in line with research (Iin Sunarti, 2018; Iskandarsyah \& Ghozali, 2012; Zhang, 2004).

Table 3. Results of Path Analysis

\begin{tabular}{rlrcccll}
\hline & & & Estimate & SE & CR & P. & Label \\
\hline PB & $<---$ & EI & .377 & .129 & 2,912 & .004 & Accepted \\
MVS & $<---$ & GMD & .326 & .129 & 2,530 & .011 & Accepted \\
PB & $<---$ & GMD & .380 & .115 & 3,298 & $* * *$ & Accepted \\
MVS & $<---$ & EI & .566 & .163 & 3,479 & $* * *$ & Accepted \\
MVS & $<---$ & FLS & .026 & .065 & .401 & 688 & Rejected \\
PA & $<---$ & PB & -.354 & .325 & $-1,089$ & 276 & Rejected \\
PA & $<---$ & MVS & .782 & .284 & 2,753 & .006 & Accepted \\
PA & $<---$ & GMD &,- 074 & .169 & -439 & 661 & Rejected \\
PA & $<---$ & FLS & -.025 & .058 & -427 & 669 & Rejected \\
\hline
\end{tabular}

Information:

PB : Learning behavior

EI : Emotional intelligence

MVS : Motivation

GMD : Lecturer teaching style

FLS : Facilities

PA : Accounting understanding

The Influence of Teaching Style Lectures on Motivation, Learning Behavior, and Understanding Accounting

Teaching Style Lecturers play an equally important role in the teaching and learning process. The results of this study stated that the Lecturer Teaching Style influences motivation. It can be seen from the significance value of 0.011 , in line with research (Aritonang, 2008). As measured by pedagogical, professional, personal, and social abilities, lecturers' teaching style is expected to foster student motivation in learning. Lecturers as role models are expected to provide good understanding, manage class well, understand how to embrace students well to learn, and interact with students to lecturers' personalities that can be used as role models for students. Lecturers who have good attitudes, personal qualities, and learning methodology can increase attachment and affection with their students (Garkaz, Banimahd, \& Esmaeili, 2011).

An introductory course in accounting is an introductory course and determinant for subsequent courses. Lecturers who teach basic subjects such as an introduction to Accounting should first see students' educational background in the classroom. Many students have backgrounds that are not from social sciences or vocational majors in Accounting. Those with non-accounting backgrounds certainly feel that accounting is a challenging new science, considering that they have never studied accounting in the previous middle class. This condition requires more attention than ever.

Lecturers are expected to provide a comprehensive understanding of all students, not only students from accounting schools. Lecturer expertise is needed here, managing the class to become more lively and how the lecturer can invite students to participate in this learning process. An active class will undoubtedly have a positive impact going forward. In teaching, lecturers need students, and students 
also need lecturers. Lecturers provide feedback, and students will provide feedback, so the learning process is carried out well and can increase student motivation. This study is in line with research (Hein et al., 2012; Munawarah, 2019).

The lecturer teaching style also influences learning behavior; this can be seen from the P-value of 0,000 . The lecturers' teaching style starts from lecturers' ability to know their students until the lecturer becomes a role model and can improve student learning behavior. Lectures are not just about attending and providing knowledge, but there are also lecturers' assignments as an exercise. Lecturers who give assignments can indirectly change student learning behavior. For example, lecturers give assignments to look for the latest research journals regarding accounting. Initially, students will consider the task as their burden, which they inevitably have to do. Eventually, this burden will become a habit (Hariyoga \& Suprianto, 2011). The lecturer who always discusses the results of student assignments in class makes a discussion of the results of thought to interpret it. The lecturer has a challenge to get good grades through assignments, making students visit the library or find references about the assignment more often.

The lecturer teaching style also does not affect the understanding of accounting. The p-value indicates the number 0.661 . This research is not in line with research conducted by (Iin Sunarti, 2018; Iskandarsyah \& Ghozali, 2012; Zhang, 2004). The ability of lecturers to manage the class to make the class more alive, of course, is not entirely appropriately achieved. Sometimes, there are still silent, even though other friends are already active. All things done in the teaching process to become better will not be achieved without the student's motivation. All lecturers' abilities are still challenging to provide a good understanding if there is no motivation from students to hear and understand everything. This research is in line with research (Murti \& Prasetio, 2018).

\section{The Influence of Facility on Motivation and Understanding of Accounting}

The facility is a determinant of student motivation in participating in teaching and learning activities (Budiadi \& Sulistyawati, 2013; Hamdu \& Agustina, 2011; Inayah et al., 2013; Muhammad et al., 2014; Nurhidayah, Tri, \& Budi, 2016). However, in this research, the facility does not affect student motivation. It can be seen from the p-value of 0.688 . To generate student motivation and support the teaching and learning process, facilities should be the main point. The reality that occurs is that facilities do not determine factors that can arouse student motivation (Kusumasari \& Rustiana, 2019). These results can be concluded that many are not used optimally to assist and support the teaching and learning process. The ever-evolving digital era compounds this fact. In the past, students went to the library and borrowed books. Nowadays, with the advancement of time, much easy access can be obtained. Many of the students more often surf the internet to find work references rather than to the library. This study is not in line with research (Aritonang, 2008; Budiadi \& Sulistyawati, 2013; Hamdu \& Agustina, 2011; Muhammad et al., 2014).

The facility does not affect the understanding of accounting. It can be seen from the p-value of 0.669 . Nowadays, with convenience in the world of technology, little by little, it has started to erode distance and shorten the time. Students can study even without adequate facilities, as long as they have a smartphone and internet quota. The facilities provided by the university, for example here, are libraries, including very rarely visited. Students more often find out and learn by surfing the internet. Measurement of this facility variable must also shift from traditional learning facilities 
to current learning facilities. It can be seen from the absence of a relationship between facilities and motivation and understanding of accounting.

Students' facilities are often not used by students because students do not have the motivation to change themselves. However, the campus is very concerned about the completeness and suitability of the existing facilities. In-class facilities such as in focus, blackboards, etc. also cannot improve student understanding. This research is not in line with research (Budiadi \& Sulistyawati, 2013; Hamdu \& Agustina, 2011; Muhammad et al., 2014), which states that facilities can influence understanding.

\section{The Influence of Learning Behavior on Understanding Accounting}

Learning behavior does not affect the understanding of accounting. It can be seen from the p-value of 0.276 . Learning behavior that was a burden turned into a habit that apparently can not influence student accounting understanding. Everything requires a firm intention and determination. Learning behavior that changes without the intention to change is also challenging. For example, visits to the library are always done but without reading and doing other positive things. It, of course, becomes useless.

Learning behavior in this study has not been able to increase the level of accounting understanding. Students were starting from the habit of reading books. The habit of reading books is directed activity. It is just that the books that are read are not books related to basic accounting. The habit of reading this book cannot be generalized to all books. Some students prefer non-fiction books to fiction books. Other learning behaviors are measured from the habits of students following lessons. It can be reflected in the number of attendance recorded in attendance. Students' habit of taking lessons is sometimes only to fulfill absences to take semester exams, not understanding. Students are often engrossed in their world when the lecturer explains the material. Some students have also been caught playing smartphone applications or recording videos to share on social media accounts. Learning behavior here has not been able to improve students' accounting understanding. This research is not in line with research (Rokhana \& Sutrisno, 2016; Yanti, 2015). However, this research is in line with (Riswandi \& Lakoni, 2017).

\section{The Influence of Motivation on Understanding of Accounting}

Motivation affects the understanding of accounting. Motivation is the key to the success of the teaching and learning process. Motivation is also a driving force for someone to do something better to achieve his life goals. Motivation in this study is the key to the teaching and learning process's success in achieving accounting understanding. Student motivation improving, a motivator is needed, both from within and from outside. The desire to achieve success from within students will lead to enthusiasm for improving self-quality improvement. Students who have the desire to improve their quality will undoubtedly show a high motivation to learn. Students who have high motivation will move to understand the lesson and act wisely when faced with failure.

One example of a motivator from outside the student is the university's support in the achievement of these students, for example, just by giving scholarships to students who excel in accounting. With the scholarship, student motivation will be encouraged and compete with each other to get good grades and understanding, where the conditions for obtaining the scholarship must certainly have exemplary learning achievements that can be shown from the value of the GPA. Moreover, most importantly, from this research, lecturers who are the primary motivators in increasing 
student motivation must recognize and understand students competently to choose a suitable and appropriate teaching style. This research is in line with research (Hamdu \& Agustina, 2011).

\section{CONCLUSION}

Based on this study's results, it can be concluded that motivation can be a link between one's emotional intelligence to achieve accounting understanding. Motivation becomes a driving force for someone to do something better to achieve his life goals. Students will try to get a good understanding of the students to motivate them to change and improve themselves. To achieve something valuable in the future, students must have the motivation to achieve it. One of them is through scholarships for outstanding students in the Department of Accounting to encourage interest and business learning more optimally from students.

This research is limited to the fourth-semester accounting student respondents at the University of Prima Indonesia. This research cannot be generalized to different respondents. In the future, suggestions that can be given for further research can add other factors that can drive motivation for the better, for example, spiritual intelligence, which is intelligence as the foundation of life, or intellectual intelligence.

\section{ACKNOWLEDGMENT}

The researcher would like to thank DRPM Kemenristekdikti for the budding lecturer research grant with the contract number: T / 63 / L1.3.1 / PT.01.03 / 2019 so that this research can be completed well. The researcher also thanks to the Chancellor of Universitas Prima Indonesia for support and facilities during the research completion process.

\section{REFERENCES}

Aritonang, K. T. (2008). Minat dan Motivasi dalam Meningkatkan Hasil Belajar Siswa. Jurnal Pendidikan Penabur, 10(7, Juni), 11-21. https:// doi.org/10.1017/CBO9781107415324.004

Budiadi, D., \& Sulistyawati, J. (2013). Pengaruh Kompetensi Dosen, Self Efficacy, Locus of Control, Fasilitas Pembelajaran terhadap Tingkat Pemahaman Mahasiswa Akuntansi. Cahaya Aktiva, 03(01), 36-47.

Dimyati \& Mudjiono. (2006). Hakikat Belajar dan Pembelajaran. In Belajar dan Pembelajaran.

Frunză, V. (2014). Implications of Teaching Styles on Learning Efficiency. Procedia Social and Behavioral Sciences, 127, 342-346. https:// doi.org/10.1016/j.sbspro.2014.03.268

Garkaz, M., Banimahd, B., \& Esmaeili, H. (2011). Factors affecting accounting students' performance: The case of students at the Islamic Azad university. Procedia - Social and Behavioral Sciences. https://doi.org/10.1016/j.sbspro.2011.11.216

Hackathorn, J., Solomon, E. D., Blankmeyer, K. L., Tennial, R. E., \& Garczynski, A. M. (2011). Learning by Doing: An Empirical Study of Active Teaching Techniques. The Journal of Effective Teaching, 11(2), 40-54.

Hamdu, G., \& Agustina, L. (2011). Pengaruh Motivasi Belajar Siswa Terhadap Pestasi Belajar IPA di Sekolah Dasar (Studi Kasus terhadap Siswa Kelas IV SDN Tarumanagara Kecamatan Tawang Kota Tasikmalaya). Jurnal Penelitian Pendidikan, 12(1), 81-86.

Hariyoga, S., \& Suprianto, E. (2011). Pengaruh Kecerdasan Emosional, Perilaku Belajar, 
Dan Budaya Terhadap Tingkat Pemahaman Akuntansi Dengan Kepercayaan Diri Sebagai Variabel Pemoderasi. SNA XIV Fakultas Ekonomi Universitas Syiah Kuala Banda Aceh, 21-22 Juli.

Hein, V., Ries, F., Pires, F., Caune, A., Emeljanovas, A., Ekler, J. H., \& Valantiniene, I. (2012). The relationship between teaching styles and motivation to teach among physical education teachers. Journal of Sports Science and Medicine, 11, 123-130.

Iin Sunarti. (2018). Pengaruh Kecerdasan Emosi Efikasi Diri dan Motivasi Belajar Terhadap Prestasi Belajar Mahasiswa Pendidikan Ekonomi UNIKU. Jurnal Penelitian Pendidikan Dan Ekonomi, 15(2), 16-33. https://doi.org/10.25134/equi.v15i02.Abstract

Inayah, R., Martono, T., \& Sawiji, H. (2013). Pengaruh Kompetensi Guru, Motivasi Belajar Siswa, dan Fasilitas Belajar terhadap Prestasi Belajar Mata Pelajaran Ekonomi pada Siswa Kelas XI IPS SMA Negeri 1 Lasem Jawa Tengah Tahun Pelajaran 2011/2012. Jurnal Pendidikan Insan Mandiri, 2(1), 1-12.

Iskandarsyah, D., \& Ghozali, I. (2012). Analisis Faktor-Faktor Yang Memengaruhi Prestasi Mahasiswa Dalam Mempelajari Matakuliah Akuntansi Keuangan Menengah (Studi empiris pada mahasiswa Jurusan Akuntansi Reguler di Fakultas Ekonomika dan Bisnis Universitas Diponegoro tahun angkatan 2009 dan 20. Diponegoro Journal of Accounting, 1(1), 289-301.

Kusumasari, N., \& Rustiana, A. (2019). Pengaruh Pengalaman Ojt, Fasilitas Belajar, Dan Lingkungan Pendidikan Terhadap Kesiapan Kerja Siswa Melalui Motivasi .... Economic Education Analysis ..., 8(1), 366-388.

Muhammad, S., Sapri, M., \& Sipan, I. (2014). Academic Buildings and Their Influence on Students' Wellbeing in Higher Education Institutions. Social Indicators Research, 1159-1178. https://doi.org/10.1007/s11205-013-0262-6

Munawarah, M. (2019). Pengaruh Kompetensi Pedagogik Dosen Terhadap Motivasi Belajar Mahasiswa Pada Mata Kuliah Statistik Deskriptif Program Studi Ekonomi Islam Jurusan Syariah dan Ekonomi Islam Stain Watampone. Ekspose: Jurnal Penelitian Hukum Dan Pendidikan, 17(2), 672-682. https://doi.org/10.30863/ekspose.v17i2.123

Murti, R., \& Prasetio, A. (2018). Pengaruh Kompetensi Dosen terhadap Prestasi Akademik Mahasiswa Fakultas Ekonomi dan Bisnis Telkom University. Jurnal Penelitian Pendidikan, 18(2), 94-102.

Novianti, N., Farida, N., \& Widiartanto, W. (2015). Pengaruh Budaya Organisasi Dan Motivasi Kerja Terhadap Kinerja Karyawan Dengan Kepuasan Kerja Sebagai Variabel Intervening (Studi Terhadap Karyawan Pt. Bpr Artha Mukti Santosa Semarang). Jurnal Ilmu Administrasi Bisnis, 4(3), 167-176.

Nuraini, F. (2017). Motivasi Belajar Mahasiswa Akuntansi Sebelum Dan Sesudah Menjadi Perguruan Tinggi Negeri (Studi Kasus Pada Mahasiswa Prodi Akuntansi Angkatan 2012 UPN “VETERAN” Jawa Timur). Journal of Accounting Science, 1(1), 51-61. https://doi.org/10.21070/jas.v1i1.790

Nurhidayah, S., Tri, A., \& Budi, L. (2016). Pengaruh Program Life Skills,Fasilitas Sekolah Dan Kemampuan Guru Terhadap Motivasi Siswa Untuk Meningkatkan Prestasi (Study Empiris Pada Siswa Kelas XI SMA PGRI 2KAYEN). Journal of Management, 2(2), 1-13.

Öztürk, S., \& Kutlu, H. A. (2017). Basic Factors That Affect The Students Attitudes Towards Accounting Courses: A Research. Marmara Business Review, 3(1), 9-30. https://doi.org/10.23892/mbrev.2018.17

Parauba, I. (2014). Pengaruh Kecerdasan Intelektial, Kecerdasan Emosional, Kecerdasan Spiritual, dan Perilaku Belajar Terhadap Pemahaman Akuntansi 
Mahasiswa Fakultas Ekonomi dan Bisnis Universitas Sam Ratulangi Manado. Jurnal Riset Akuntansi Going Concern, 9(2), 53-67.

Ramaraju, A. (2015). a Study on Emotional Quotient Vs Intelligence Quotient of Management Students. International Journal of Management, 6(4), 59-62.

Riswandi, P., \& Lakoni, I. (2017). Pengaruh Kecerdasan Emosional, Kecerdasan Spritual Dan Kecerdasan Intelektual Terhadap Pemahaman Mata Kuliah Pengantar Akuntansi Dengan Perilaku Belajar Sebagai Variabel Moderasi Di PTN Dan PTS Kota Bengkulu. Journal of Accounting Science, 1(2), 143-153. https://doi.org/10.21070/jas.v1i2.972

Rokhana, L. A., \& Sutrisno, S. (2016). Pengaruh Kecerdasan Emosional, Perilaku Belajar Dan Minat Belajar Terhadap Tingkat Pemahaman Akuntansi. Media Ekonomi Dan Manajemen, 31(1), 26-38.

Sari, Y. K. (2013). Pengaruh Pengendalian Diri Dan Perilaku Belajar Terhadap Tingkat Pemahaman Pengantar Akuntansi. Journal of Chemical Information and Modeling, 1(1), 1-17. https://doi.org/10.1017/CBO9781107415324.004

Sideridis, G. D., \& Kaissidis-Rodafinos, A. (2001). Goal importance within planned behaviour theory as "the" predictor of study behaviour in college. British Journal of Educational Psychology, 71(4), 595-618. https:// doi.org/10.1348/000709901158695

Steenkamp, L., Baard, R., \& Frick, L. (2009). Student Perceptions of the Factors Influencing their Success in First-year Accounting. Focus on First-Year Sucess Perspectives Emerging from South Africa and Beyond. https://doi.org/10.18820/9781920338220/10

Susanti, S., Rispantyo, \& Kristianto, D. (2017). Pengaruh Minat Belajar, Perilaku Belajar, Kecerdasan Intelektual, dan Kecerdasan Emosional Terhadap Tingkat Pemahaman Akuntansi. Jurnal Akuntansi Dan Sistem Teknologi Informasi, 13, 127134.

Yanti, D. A. (2015). Analisis Faktor-Faktor Yang Mempengaruhi Tingkat Pemahaman Akuntansi Mahasiswa Jurusan Akuntansi Stie Mikroskil Medan. Jurnal Wira Ekonomi Mikroskil, 5(1), 11-20.

Zhang, L. F. (2004). Thinking styles: University students' preferred teaching styles and their conceptions of effective teachers. Journal of Psychology: Interdisciplinary and Applied, 138(3), 233-252. https:// doi.org/10.3200/JRLP.138.3.233-252 